\title{
LEVEL OF READINESS AND ACCEPTANCE OF MAINSTREAM TEACHERS TOWARDS THE IMPLEMENTATION OF INCLUSIVE EDUCATION IN LEARNING DISABILITY
}

\author{
NIK HASSAN SEMAN* \\ MOHD ISKANDAR DAUD** \\ NOR KAMILAH MAKHTAR ${ }^{* * *}$ \\ NIK AZHAR NIK AB RAHMAN*** \\ FARAH DILLA RAMLI $I^{* * * *}$
}

nikhassanseman@gmail.com*, iskandar16-15@epembelajaran.edu.my**,

nkamilahm@gmail.com ${ }^{* * *}$, kopratasa@gmail.com ${ }^{* * * *}$, farah16-110@epembelajaran.edu.my*****

\begin{abstract}
Inclusive Education Program (IEP) is a challenging educational transformation as the teachers who are involved in it need to equip themselves with a strong field of knowledge, sound teaching skills as well as commendable attitudes. This study aims to examine the state of readiness of mainstream teachers in terms of knowledge and acceptance of the implementation of the Inclusive Education Program for learning disabilities. A total of 80 mainstream teachers in several primary schools in the district of Kota Bharu Kelantan were selected as respondents in this study. Data were collected through an online survey using a google form questionnaire and were analyzed descriptively. The findings show that the involved mainstream teachers have a high level of state of readiness in terms of knowledge of the Inclusive Education Program, while in the aspect of acceptance, most respondents obtained a moderate level. The results of this study show that many efforts and programmes are needed to help improve knowledge and the level of acceptance among mainstream teachers to successfully implement an Inclusive Education Program for learning disability.
\end{abstract}

Keywords: Inclusive Education, Learning Disability, Mainstream

Submitted: 27 April 2021

Revised: 14 June 2021

Published: 30 September 2021

* Senior lecturer at Department of Special Education, Teachers Education Institute Kota Bharu Campus, Malaysia.

** Senior lecturer at Department of Language, Teachers Education Institute Kota Bharu Campus, Malaysia.

*** Senior lecturer at Department of Research and Innovation Planning, Teachers Education Institute Kota Bharu Campus, Malaysia.

**** Senior lecturer at Department of Special Education, Teachers Education Institute Kota Bharu Campus, Malaysia.

***** Senior lecturer at Department of Special Education, Teachers Education Institute Kota Bharu Campus, Malaysia 


\title{
TAHAP KESEDIAAN DAN PENERIMAAN GURU ARUS PERDANA TERHADAP PELAKSANAAN PENDIDIKAN INKLUSIF DALAM MASALAH PEMBELAJARAN
}

\author{
NIK HASSAN SEMAN* \\ MOHD ISKANDAR DAUD** \\ NOR KAMILAH MAKHTAR*** \\ NIK AZHAR NIK AB RAHMAN**** \\ FARAH DILLA RAMLI***** \\ nikhassanseman@gmail.com*, iskandar16-15@epembelajaran.edu.my**, \\ nkamilahm@gmail.com***, kopratasa@gmail.com***, farah16-110@epembelajaran.edu.my ${ }^{* * * * *}$
}

\begin{abstract}
Abstrak
Program Pendidikan Inklusif (Inclusive Education Programme, IEP) merupakan satu program transformasi Pendidikan negara yang mencabar kerana guru yang terlibat perlu melengkapkan diri dengan pengetahuan pendidikan inklusif yang mantap, kemahiran mengajar yang baik dan memiliki sikap yang terpuji. Kajian ini bertujuan untuk mengkaji tahap kesediaan guru arus perdana dari segi pengetahuan dan penerimaan pelaksanaan IEP dalam masalah pembelajaran. Seramai 80 orang guru arus perdana di beberapa sekolah rendah di daerah Kota Bharu, Kelantan telah dipilih sebagai responden kajian. Data dikumpulkan melalui kaedah tinjauan menggunakan borang soal selidik Google Form secara atas talian dan dianalisis secara deskriptif. Dapatan kajian menunjukkan guru arus perdana yang terlibat mempunyai tahap kesediaan yang tinggi dalam aspek pengetahuan berkaitan IEP, manakala dalam aspek penerimaan, majoriti responden menunjukkan tahap yang sederhana. Hasil kajian ini menunjukkan perlunya pelbagai usaha dan program dijalankan bagi membantu meningkatkan pengetahuan dan tahap penerimaan dalam kalangan guru arus perdana untuk melaksanakan IEP dalam kategori masalah pembelajaran.
\end{abstract}

Kata Kunci: Pendidikan Inklusif, Ketidakupayaan Pembelajaran, Arus Perdana

* Pensyarah Kanan di Jabatan Pendidikan Khas, Institut Pendidikan Guru Kampus Kota Bharu, Malaysia

** Pensyarah Kanan di Jabatan Bahasa, Institut Pendidikan Guru Kampus Kota Bharu, Malaysia

*** Pensyarah Kanan di Jabatan Perancangan Penyelidikan Dan Inovasi, Institut Pendidikan Guru Kampus Kota Bharu, Malaysia

**** Pensyarah Kanan di Jabatan Pendidikan Khas, , Institut Pendidikan Guru Kampus Kota Bharu,Malaysia

***** Pensyarah Kanan di Jabatan Pendidikan Khas, Institut Pendidikan Guru Kampus Kota Bharu,Malaysia 


\subsection{Introduction}

Inclusive Education Programme (IEP) is an educational programme attended by students with special learning needs together with other students in the same class in government schools or government-aided schools. Though the practice of inclusive education had been implemented for a long time, it was not previously introduced directly. The programme earlier was only implemented through integration education plans and merged classes. However, the government has intended and taken the initiative to increase the enrollment of students with special learning needs in IEP as stipulated in the Malaysian Education Blueprint 2013 - 2025.

The implementation of IEP demonstrates the government's noble effort to provide equal educational opportunities to all students regardless of their disability and learning needs. As the engagement of IEP is based on the initiative of the school and special education teachers, the cooperation of other involving teachers is needed to ensure the success of this programme so that the needs of students with special learning needs are not neglected (Sue, 2012).

The readiness of teachers in implementing IEP, especially the mainstream teachers, is a key indicator that will determine the success of this programme as they are part of the team that runs the IEP in their schools. Accordingly, this study was conducted to examine some aspects of readiness of the mainstream teachers in implementing IEP for special learning needs students in their schools. Besides that, in a wider spectrum, this research aimed to improve the performance of students with special learning needs as well as improving the pedagogical practices of teachers teaching them. (Nik Hassan Seman, 2016, Zawawi 2017; Manisah, Norshidah dan Zalizan 2010; Rose dan Howley 2007)

\section{.2.0 Problem Statement}

To date, there are very few studies related to students with a learning disability had been done, let alone the ones conducted specifically for students with special learning needs or learning disabilities (Nik Hassan Seman, 2019; Mohd Hanafi, 2016). On the same note, the mainstream teachers were given little exposure to how to play their roles in IEP in Malaysia. These may be the reason why the implementation of IEP in our country has been described by some researchers as unsuccessful (Zawawi 2017; Manisah, Norshidah dan Zalizan 2010; Rose dan Howley 2007). According to the study, the failure of students with special learning needs to be fully involved in IEP is due to improper planning and implementation of the programme failing to meet its actual objectives. Some various issues and challenges arose from the failure of IEP implementation in schools, one of which is the readiness of teachers.

According to Zaharah Badri (2013), the readiness of the teachers involved, especially the mainstream teachers should be emphasized because they are the main indicator in determining the success of this program. Their readiness from the aspects of knowledge and acceptance to be involved in the implementation of IEP for learning disability is very important because it has an impact on their performance and commitment when this programme is implemented. This is because there are still some of them who have negative views towards the presence of students with learning disabilities in the 
mainstream class. They dispute the appropriateness of the implementation of IEP, do not welcome the students, and try to avoid having the inclusive students participate in their teaching and learning sessions using various reasons (Mohd Hanafi, 2016). The question here is to what extent are these mainstream teachers ready to accept the implementation of this program?

Thus, this survey study aimed to investigate the state of readiness of mainstream teachers in the implementation of IEP for learning disabilities. The teachers' state of readiness in this study was studied through two levels, namely the level of knowledge in the field and their level of acceptance of this program. The respondents in this study were 80 primary school teachers from the district of Kota Bharu in the state of Kelantan.

\subsection{Purpose of the Study}

This study aimed to identify the level of knowledge of mainstream teachers in the implementation of the IEP for learning disability in the district of Kota Bharu, Kelantan. In addition, it also aimed to see the level of acceptance of mainstream teachers in the implementation of this programme and to determine the differences in the level of readiness of these mainstream teachers based on their academic background.

\subsection{Significance of the study}

This study is significant because it can increase the understanding of mainstream teachers who are directly involved in IEP to be more open-minded, willing to participate, and accepting of the presence of special needs students in the mainstream classrooms. Furthermore, this study can also provide feedback to schools or administrators so they can give better guidance and support to mainstream teachers in improving their level of knowledge and acceptance of IEP. At the level of the Ministry of Education Malaysia, it's hoped that this study can provide useful information on the readiness of mainstream teachers in the implementation of IEP and further expand this programme to help special needs students especially students with a learning disability.

\subsection{Literature Review}

Several studies have shown that many still do not understand about IEP in Malaysia and abroad (Abdul Rahim, 2019; Mohd Najib dan Sanisah, 2006; Maizatul Asmah, 2015; Saiful Azam, 2019; Pratiwi dan Annisa, 2018; Endis, 2010; Abdul Razaq, 2010; Othman, 2008; Supiah,2019; Muhammad Radhana, 2017; Nissa, 2016; Mohamad Sugiarmin, 2010). This lack of knowledge and exposure to IEP does not only occur in our country but also in other countries such as Indonesia. This shows that public awareness of IEP is still lacking and not many people are aware of the existence of this programme specifically. Despite this lack of awareness, not many studies focused on the state of readiness of teachers in terms of knowledge and acceptance to implement IEP for students with learning problems. On the same note, studies on the level of knowledge of IEP among mainstream teachers, especially for students with special learning needs in Malaysia are still low. When teachers lacked knowledge about special needs students then usually they will be less concerned 
about them. This assumption is made based on the finding of the study by Supiah Saad (2003) in which she found only 12 percent (about 1/8) of mainstream preschool teachers know the definition of IEP.

\subsection{Methodology}

This study is descriptive using a survey method. The locations of the study were chosen based on the academic achievement of the schools as well as because both schools run IEP for students with special learning needs. There are 3 variables in this study. They are the level of knowledge, the level of acceptance, and the academic background.

An online research instrument in the form of a google form questionnaire was used in the study. Blankers, Grohol dan Prochaska (2012) assert that the use of online surveys facilitates the collection of data findings because the respondents involved can be recontacted and it saves cost, energy, and time. Questionnaires were given to the target group consisting of mainstream teachers. These respondents were selected from mainstream teachers who are teaching in government schools in the district of Kota Bharu Kelantan. A total of 80 people were first selected using the purposive sampling method, then later were carefully chosen using simple random sampling. This would give equal opportunity for all respondents to be selected (Sidek Mohd Noah, 2002).

The questionnaires used in the study were adapted from previous studies, which have undergone a verification process and tested for their reliability using the Quality Indicators for Effective Inclusive Education handbook from the New Jersey Coalition for Inclusive Education (NJCIE, 2013) and Scale of Teachers' Attitudes Toward Inclusive Classrooms (STATIC) developed by Cochran (1998) as a guide. These were later amended by the researchers to accommodate this study. The items in the questionnaires were divided into 3 parts. Section A had 6 questions covering the general demographics of teachers, Sections $B$ and $C$ each had a total of 10 items using measurements in the form of a Likert scale. The scales used in this study ranged from strongly disagree, disagree, uncertain, agree, and strongly agree. Items 1 to 10 in Section B were placed to see the level of knowledge of mainstream teachers towards inclusive programs while the 10 items in section $C$ were used to see the level of acceptance of mainstream teachers towards inclusive programs.

A pilot study was conducted on 22 samples consisting of mainstream teachers from several schools in a few districts in Kelantan. In the pilot study, the researchers selected schools that have an integrated special education programme for learning disabilities. The reason for this is that schools that run an integrated special learning programme for learning disabilities are highly likely to run an IEP as well. This pilot study was conducted to confirm the findings from the instrument whose reliability has been verified. Data obtained from the pilot study were analyzed to measure the reliability of the research instrument by looking at the Cronbach's Alpha coefficient value as indicated in Table 1. The ideal Cronbach's Alpha coefficient value is 0.70 and above (Bond dan Fox, 2007). The results of the a pilot study found that all variables were at a high level with an average Cronbach's Alpha value of 0.851 as indicated in Table 2. 
Table 1: Cronbach Alpha Score Interpretation.

(Source: Zaihan dan Hilmun, 2016).

\begin{tabular}{|c|c|}
\hline Value & Interpretation \\
\hline $0.9-1.0$ & Very good, effective, high level of consistency \\
\hline $0.7-0.8$ & Good and Acceptable \\
\hline $0.6-0.7$ & Acceptable \\
\hline$<0.6$ & Items need to be modified \\
\hline$<0.5$ & Items need to be dropped \\
\hline
\end{tabular}

Several methods of data analysis were used to get the answers to research questions. Data were analyzed using Statistical Package for the Social Sciences (SPSS) version 19.0. Data analysis began by differentiating the obtained data from the chosen schools. The findings of each school were used as a basis for comparison in looking for the differences in the pre-determined aspects of the questionnaires. All data from the questionnaires were analyzed using descriptive and inference analyses involving frequency, percentage, mean, standard deviation, and one-way ANOVA to answer the research questions. For descriptive statistical analysis of mean, the researchers used the interpretation of mean scores based on sources from Zaihan dan Hilmun (2016). The interpretation of the mean score is shown in Table 2.

Table 2: Interpretation of Mean Score

(Source: Zaihan dan Hilmun, 2016).

\begin{tabular}{|c|c|}
\hline Mean Score & Interpretation \\
\hline $0.9-1.0$ & Very Low $(\mathrm{VL})$ \\
\hline $0.7-0.8$ & Low $(\mathrm{L})$ \\
\hline $0.6-0.7$ & Medium $(\mathrm{M})$ \\
\hline$<0.6$ & High $(\mathrm{H})$ \\
\hline$<0.5$ & Very High $(\mathrm{VH})$ \\
\hline
\end{tabular}

\subsection{Results and Discussion}

\subsection{Demographic Analysis}

A total of 80 respondents consisting of mainstream teachers from several schools in the district of Kota Bharu, Kelantan were involved. Out of the total number, 43 $(53.7 \%)$ were female respondents while male respondents came in at $46.3 \%$ (37 teachers). The majority of respondents, 71 teachers, have a bachelor's degree and this is equivalent to $88.8 \%$. This is followed by respondents who have studied to the master's level with 4 people or $5.0 \%$, then those who have a diploma with 3 people with the equivalent to $3.8 \%$. Meanwhile, there were only 2 respondents with Sijil Pelajaran Malaysia (SPM) level with the equivalent of $2.4 \%$ and there were no respondents with STPM qualification as indicated in Table 3. 
Profiles based on teaching experience show that the majority of respondents have teaching experience for 16 years and above with 25 people or $31.2 \%$. Respondents with teaching experience of 11 to 15 years recorded a total of 18 people or $22.5 \%$. Next, the respondents who have 6 to 10 years of teaching experience are 5 or $6.3 \%$, and 1 to 5 years teaching experience is the least with 3 people or $4.0 \%$.

The distribution of respondents involved in this study was also analyzed based on their exposure to special education courses they attended. The findings show that a total of 51 respondents $(63.7 \%)$ had never participated in any special education courses. Only 29 respondents (36.3\%) had attended the said courses.

Table 3: Demographic Analysis

\begin{tabular}{|c|l|c|c|}
\hline Information & \multicolumn{1}{|c|}{ Category } & Frequency (N=80) & Percent (\%) \\
\hline \multirow{3}{*}{ Gender } & Male & 37 & 46.3 \\
\cline { 2 - 4 } & Female & 43 & 53.7 \\
\hline \multirow{4}{*}{ Qualification } & SPM & 2 & 2.4 \\
\cline { 2 - 4 } & STPM & 0 & 0.0 \\
\cline { 2 - 4 } & Diploma & 3 & 3.8 \\
\cline { 2 - 4 } & Bachelor's Degree & 71 & 88.8 \\
\cline { 2 - 4 } & Master's Degree & 4 & 5.0 \\
\hline \multirow{3}{*}{ Teaching Experience } & $1-5$ years & 25 & 31.2 \\
\cline { 2 - 4 } & 6-10 years & 5 & 22.3 \\
\cline { 2 - 4 } & $11-15$ years & 18 & 40.0 \\
\cline { 2 - 4 } & More than 16 years & 32 & 36.3 \\
\hline Special Education & Yes & 29 & 63.7 \\
\cline { 2 - 4 } & No & 51 & \\
\hline
\end{tabular}




\subsection{Level of Knowledge of Mainstream Teachers on IEP}

This section contains 10 items related to the level of knowledge of mainstream teachers on IEP. Based on Table 5, the overall mean for all items is 4.04 with a standard deviation of 0.77 placed at a high level of mean interpretation (3.50 4.29) (Zaihan dan Hilmun, 2016). The findings show that 8 out of 10 items are placed at a high level with a mean value between 3.60 to 4.21 . This indicated that the level of knowledge of mainstream teachers in the district of Kota Bharu Kelantan on IEP is at a high level suggesting that these teachers understand what IEP is all about. This concured with a study conducted by Kezar dan Kerlinger (2006) when they found that the majority of teachers are in agreement with the inclusive education concept. This paints the picture that inclusive education is a practical educational program. In addition, the other 2 items are also positioned at a very high level (4.30-5.00) with a mean value between 4.41 to 4.51 .

Table 5: Frequency distribution, percentage, mean score and standard deviation on mainstream teachers' level of knowledge on IEP

\begin{tabular}{|c|c|c|c|c|c|c|c|c|}
\hline No. & Item & $\begin{array}{c}\text { SD } \\
f \\
\% \\
\end{array}$ & $\begin{array}{c}\mathbf{D} \\
\mathrm{f} \\
\% \\
\end{array}$ & $\begin{array}{c}\mathbf{U} \\
\mathrm{f} \\
\%\end{array}$ & $\begin{array}{c}\mathrm{A} \\
\mathrm{f} \\
\% \\
\end{array}$ & $\begin{array}{c}\text { SA } \\
f \\
\% \\
\end{array}$ & Min & $\begin{array}{l}\text { Std } \\
\text { Dev. }\end{array}$ \\
\hline 1 & $\begin{array}{l}\text { Given exposure to } \\
\text { inclusive education by } \\
\text { SED / DEO / SE } \\
\text { Senior Teacher / SE } \\
\text { Coordinator or others }\end{array}$ & 22.5 & 56.3 & 1417.5 & 4758.7 & 1215.0 & 3.80 & 0.87 \\
\hline 2 & $\begin{array}{l}\text { Special education } \\
\text { students who qualify } \\
\text { and meet certain } \\
\text { criteria need to be } \\
\text { included }\end{array}$ & 22.5 & 810.0 & 2430.0 & 3442.4 & 1215.0 & 3.60 & 0.95 \\
\hline 3 & $\begin{array}{l}\text { I understand the } \\
\text { meaning of IEP }\end{array}$ & 22.5 & 45.0 & 1721.3 & 4050.0 & 1721.3 & 3.83 & 0.91 \\
\hline 4 & $\begin{array}{l}\text { IEP is necessary for } \\
\text { children with special } \\
\text { learning needs }\end{array}$ & 00.0 & 11.3 & 810.0 & 4556.2 & 2632.5 & 4.20 & 0.66 \\
\hline 5 & $\begin{array}{l}\text { I know the } \\
\text { requirements needed } \\
\text { for inclusion into } \\
\text { mainstream class }\end{array}$ & 22.5 & 56.3 & 2328.7 & 3948.8 & 1113.8 & 3.65 & 0.88 \\
\hline 6 & $\begin{array}{l}\text { I know the ruling that } \\
\text { all children with } \\
\text { special needs are } \\
\text { entitled to education }\end{array}$ & 00.0 & 11.3 & 22.5 & 3240.0 & 4556.2 & 4.51 & 0.61 \\
\hline 7 & $\begin{array}{l}\text { Special needs } \\
\text { students need to be } \\
\text { included in the } \\
\text { mainstream class to } \\
\text { improve their } \\
\text { academic } \\
\text { achievement }\end{array}$ & 11.3 & 22.5 & 810.0 & 3746.2 & 3240.0 & 4.21 & 0.82 \\
\hline 8 & $\begin{array}{l}\text { I know the advantages } \\
\text { of IEP to children with } \\
\text { special needs }\end{array}$ & 00.0 & 22.5 & 1417.5 & 4455.0 & 2025.0 & 4.03 & 0.72 \\
\hline 9 & $\begin{array}{l}\text { The IEP programme } \\
\text { will bring positive } \\
\text { development to }\end{array}$ & 00.0 & 11.3 & 911.3 & 4555.0 & 2525.0 & 4.17 & 0.67 \\
\hline
\end{tabular}




\begin{tabular}{|c|l|l|l|l|l|l|l|c|}
\hline & $\begin{array}{l}\text { children with special } \\
\text { needs }\end{array}$ & & & & & & & \\
\hline 10 & $\begin{array}{l}\text { Successful } \\
\text { implementation of IEP } \\
\text { requires specialized } \\
\text { training for teachers }\end{array}$ & 00.0 & 00.0 & 45.0 & 3948.8 & 3746.2 & 4.41 & 0.58 \\
\hline $\begin{array}{l}\text { Average f } \\
\%\end{array}$ & 11.1 & 33.65 & 1215.4 & 4050.2 & 2429.7 & 4.04 & 0.77 \\
\hline
\end{tabular}

\subsection{Level of Acceptance of Mainstream Teachers on IEP}

Based on Table 6, the item that shows the highest mean value is item 3 where the mainstream teachers feel that the needs of students with special learning needs can be better presented in special education classes (mean $=4.41, \mathrm{sp}=0.63$ ) while the item with the lowest mean value is item 1 (mean $=2.65, \mathrm{sp}=0.99$ ) that designates all children need to learn regular classroom. The overall mean value of the item for teacher acceptance of IEP is $3.47 \mathrm{~s}$ at a moderate level. Therefore, in general, the acceptance of mainstream teachers in the district of Kota Bharu Kelantan towards the implementation of IEP for learning disability is only moderate. Consequently, the readiness of mainstream teachers in terms of acceptance should be given emphasis so that this inclusive implementation can be carried out systematically to achieve goals. This is crucial because the mainstream primary school teachers are also responsible to ensure that IEP can be implemented successfully (Saiful Azam, 2019). Hence, mainstream teachers' acceptance of students with special learning needs should be given special attention in the implemention of IEP.

Table 6: Frequency distribution, percentage, mean score and standard deviation on teacher acceptance level

\begin{tabular}{|c|c|c|c|c|c|c|c|c|}
\hline \multirow[t]{2}{*}{ No. } & \multirow[t]{2}{*}{ Item } & SD & D & $\mathbf{U}$ & A & SA & \multirow[t]{2}{*}{ Min } & \multirow{2}{*}{$\begin{array}{c}\text { Std } \\
\text { Dev. }\end{array}$} \\
\hline & & $\begin{array}{c}\mathrm{f} \\
\%\end{array}$ & $\begin{array}{c}f \\
\%\end{array}$ & $\begin{array}{c}f \\
\%\end{array}$ & $\begin{array}{c}f \\
\%\end{array}$ & $\begin{array}{l}f \\
\%\end{array}$ & & \\
\hline 1 & $\begin{array}{l}\text { All children need to } \\
\text { study in a regular } \\
\text { classroom }\end{array}$ & 78.6 & 3543.8 & 1923.8 & 1721.3 & 22.5 & 2.65 & 0.99 \\
\hline 2 & $\begin{array}{l}\text { I believe that every } \\
\text { child regardless of } \\
\text { disability has the } \\
\text { right to study in the } \\
\text { mainstream class }\end{array}$ & 67.5 & 2632.5 & 1822.5 & 2430.0 & 67.5 & 3.00 & 1.11 \\
\hline 3 & $\begin{array}{l}\text { The needs of } \\
\text { students with } \\
\text { special needs can } \\
\text { be better presented } \\
\text { in special education } \\
\text { classes }\end{array}$ & 00.0 & 00.0 & 67.5 & 3543.8 & 3948.7 & 4.41 & 0.63 \\
\hline 4 & $\begin{array}{l}\text { Children with } \\
\text { severe disabilities } \\
\text { should be } \\
\text { educated in special } \\
\text { education classes } \\
\text { separately }\end{array}$ & 22.5 & 33.8 & 45.0 & 3948.7 & 3240.0 & 4.20 & 0.89 \\
\hline
\end{tabular}




\begin{tabular}{|c|l|c|c|c|c|c|c|c|}
\hline 5 & $\begin{array}{l}\text { I feel comfortable } \\
\text { working with children } \\
\text { with disabilities }\end{array}$ & 45.0 & 7 & 24 & 30 & 15 & 3.56 & 1.05 \\
\hline 6 & $\begin{array}{l}\text { IEP is only } \\
\text { theoretically good } \\
\text { but impractical }\end{array}$ & 22.5 & 2025.0 & 3240.0 & 1721.3 & 911.2 & 31.4 & 1.00 \\
\hline 7 & $\begin{array}{l}\text { The admission of } \\
\text { students with } \\
\text { special learning } \\
\text { needs in regular } \\
\text { classrooms } \\
\text { benefits students in } \\
\text { the mainstream }\end{array}$ & 45.0 & 1923.8 & 2936.3 & 2328.8 & 56.1 & 3.07 & 0.99 \\
\hline 8 & $\begin{array}{l}\text { I feel burdened with } \\
\text { the obligation to } \\
\text { teach students with } \\
\text { special learning } \\
\text { needs because of } \\
\text { differing levels of } \\
\text { achievements } \\
\text { between the two } \\
\text { sets of students }\end{array}$ & 00.0 & 00.0 & 1518.7 & 4860.0 & 1721.3 & 4.03 & 0.63 \\
\hline 9 & $\begin{array}{l}\text { The IEP system is } \\
\text { more effective than } \\
\text { special education } \\
\text { program }\end{array}$ & 22.5 & 56.1 & 3746.4 & 2835.0 & 810.0 & 3.44 & 0.85 \\
\hline 10 & $\begin{array}{l}\text { IEP increases the } \\
\text { workload of } \\
\text { mainstream teachers }\end{array}$ & 11.13 & 2227.5 & 2825.0 & 1620.0 & 1316.2 & 3.22 & 1.06 \\
\hline $\begin{array}{l}\text { Average f } \\
\%\end{array}$ & 33.51 & 1417.1 & 2126.5 & 2834.6 & 1518.2 & 3.47 & 0.92 \\
\hline
\end{tabular}

\subsection{State of Readiness of Mainstream Teachers on IEP implementation Based on Academic Background}

There was no significant difference in the level of knowledge readiness of IEP among mainstream teachers based on their academic background $(r=0.371, p>$ 0.05 ) as indicated in Table 7. This proves that the level of knowledge of mainstream teachers in inclusive education is not influence by their academic background. So, even if these mainstream teachers have high academic background, this does not necessarily reflect their level of knowledge of inclusive education.

Table 7: One-way ANOVA analysis of teachers' knowledge level based on academic background

\begin{tabular}{|l|c|c|c|c|c|}
\hline $\begin{array}{l}\text { Level of } \\
\text { Knowledge }\end{array}$ & Ss & df & MS & F & Sig. \\
\hline Inter-groups & .737 & 3 & .246 & 1.061 & .371 \\
\hline Intra-groups & 17.588 & 76 & .231 & & \\
\hline Total & 18.235 & 79 & & & \\
\hline
\end{tabular}

Based on Table 8, there is no significant difference in the level of acceptance of mainstream teachers in the implementation of IEP for learning disability based on 
the academic background of the teachers $(r=0.286, p>0.05)$. This proves that the level of acceptance of mainstream teachers of IEP is not influenced by their academic background. Thus, high academic background does not necessarily reflect high acceptance of IEP. On the other hand, if mainstream teachers have low academic background, their level of acceptance of inclusive education will not necessarily be low.

Table 8: One-way ANOVA analysis of teachers' level of acceptance based on academic background

\begin{tabular}{|c|c|c|c|c|c|}
\hline $\begin{array}{c}\text { Acceptance } \\
\text { Level }\end{array}$ & Ss & df & MS & F & Sig. \\
\hline Inter-groups & .452 & 3 & .151 & 1.283 & .286 \\
\hline Intra-groups & 8.916 & 76 & .111 & & \\
\hline Total & 9.368 & 79 & & & \\
\hline
\end{tabular}

\subsection{Conclusion}

Overall, the study found that the level of knowledge of mainstream teachers in the implementation of IEP for learning disability in the district of Kota Bharu Kelantan is high but contrastingly, their level of acceptance in the implementation of the programme is only at a moderate level. Hence, it can be concluded that the mainstream teachers understand the importance of implementing IEP for learning disabilities and do not refute the idea of the programme in their schools. However, they are in some way, a bit reluctant to be involved in the programme when they rated their level of acceptance of the programme at a relatively moderate level.

The researchers feel enrichments in terms of training and knowledge related to IEP are paramount to help increase the level of knowledge of mainstream teachers as well as opening their eyes to accept students with special learning needs into IEP. This can ensure that IEP is implemented more effectively. Ongoing exposure by concerned authorities such as the Department of Special Education or the State Education Department on IEP may help increase the readiness of these mainstream teachers in the implementation of this program.

This study has proven the importance of making sure mainstream teachers have the right levels of knowledge and acceptance for the IEP to have positive implications on the education sector in Malaysia. All concerned educational units should both play their role and work well together to help students with special learning needs achieve their optimal abilities. These include the involvement of mainstream primary school pupils, special education teachers, and mainstream teachers, as well as parents. All these parties need to collaborate so that they can help students with special learning needs interact and improve their abilities and capabilities. 


\section{References}

Blankers, M., Grohol, J. dan Prochaska. J.J. (2012). Broad Reach and Targeted Recruitment Using. New Jersey: Pearson Education, Inc.

Bond, T. dan Fox, C. (2007). Applying the Rasch model: Fundamental measurement in the human sciences (2nd). Mahwah, NJ: LEA.

Cochran, H. K. (1998). Differences in teachers: Attitudes toward inclusive education as measured by the Scale of Teachers Attitudes towards Inclusive Classrooms. Paper presented at the annual meeting of the Midwestern Educational Research Association, Chicago, IL

Kezar, A. dan Klingner, J. (2006). Redesigning for collaboration in learning initiatives: An examination of four highly collaborative campuses. Journal of Higher Education, 77(5), 19-31.

Manisah Mohd Ali, Norshidah Mohamad Salleh dan Zalizan Mohd Jelas. (2010). Developing the Foundations of Inclusive Education through University-School Partnership. International Journal of Learning, 17(4), 145-156. Doi: 10.18848/1447-9494/CGP/v17i06/47094

Mohd Hanafi Mohd Yasin. (2016). Pelaksanaan Program Pendidikan Inklusif Murid Berkeperluan Khas dalam Pelan Pembangunan Pendidikan Malaysia 2013-2015.http:/ www.researchgate.net/publication/299447306

New Jersey Coalition for Inclusive Education (NJCIE). (2013). Quality Indicators for Effective Inclusive Education Guidebook. New Jersey: New Jersey Council on Developmental Disabilities under Contract http://njcie.org/wp

Nik Hassan Seman, Muhammad Ridzuan Idris, Mohd Iskandar Daud, Nik Azhar Nik Ab. Rahman, Mohd Nazri Abdul Rahman (2019). Teaching al-Quran to deaf students: Challenges for Islamic education teachers. The online journal of Islamic education. April 2019, Vol. 7, Issue

Nik Hassan Seman. (2016). Permasalahan Pengajaran Pendidikan Islam Peringkat Sekolah Menengah Dalam Kalangan Pelajar Pekak. Tesis Doktor Falsafah Universiti Sultan Zainal Abidin content/uploads/Quality_Indicators_Manual_2013.pdf

Saiful Azam. (2017). Program Pendidikan Inklusif Bagi Murid-Murid Berkeperluan Khas di Malaysia. http:/www.researchgate.net/publication/299447306

Sidek Mohd Noah. (2002). Rekabentuk penyelidikan: Falsafah, teori dan praktis. Serdang: Penerbit UPM.

Sue. (2012). Isu Pendidikan Inklusif. Taken from http://cikgusuepkhas.blogspot.com/2012/02/isupendidikan-inklusif.html

Zaharah Badri. (2013). Kajian Kes Ke Atas Program Pendidikan Inklusif Di Sekolah Aliran Perdana. Jurnal Pendidikan, 1(14), 345-365.

Zaihan Haron dan Hilmun Mohamed. (2016). Tahap Efikasi Dengan Skor Pemantauan Pembelajaran Dan Pengajaran Pensyarah Di Politeknik Melaka. Journal of Social Sciences 
and Humanities, 1(1). Diperoleh daripada www.jonatuansarjowo.info/korelasi/ korelasi.htm

Zawawi Zahari. (2017). Pelaksanaan pendidikan inklusif bagi murid-murid masalah pembelajaran di sekolah rendah. Bangi: Penerbit UKM. 